NBER WORKING PAPER SERIES

\title{
DEBT PROBLEMS AND THE WORLD MACRO ECONOMY
}

\author{
Rudiger Dornbusch
}

Working Paper No. 2379

\section{NATIONAL BUREAU OF ECONOMIC RESEARCH 1050 Massachusetts Avenue \\ Cambridge, MA 02138 \\ September 1987}

Support from the Ford Foundation and the Rockefeller Brothers Fund is gratefully acknowledged. The research reported here is part of the NBER's research program in International Studies. Any opinions expressed are those of the author and not those of the National Bureau of Economic Research. 
NBER Working Paper \#2379

September 1987

Debt Problems and the World Macro Economy

\section{ABSTRACT}

This paper investigates the role of interest rates, commodity prices, growth in bringing the debt crisis about and how they facilitated or made more difficult the first five years of adjustment. We also ask whether and how the world macroeconomy is likely to contribute to the solution of the debt problem in the next five years.

The paper starts with a conceptual framework and a review of the behavior of key macroeconomic variables in the past quarter of a century. Next the origins of the debt crisis are discussed as well as the adjustment period, 1982-1987. The following part reviews alternative scenarios for the period 1987-90 and their bearing on debt questions. We also ask what contribution to expect from commercial policies. The paper concludes pessimistically that for many debtors there is not a sufficient improvement to be expected from good performance of the world economy.

Rudiger Dornbusch

E52-357

MIT

Cambridge, MA 02139

(617) 253-3648 


\section{DEBT PROBLEMS AND THE WORLD MACRO ECONOMY \\ Rudiger Dornbusch Massachusetts Institute of Technology and \\ National Bureau of Economic Research}

This paper discusses the role of world macroeconomic factors in contributing to the debt crisis. We investigate what role these factors--interest rates, commodity prices, growth-- played in bringing the debt crisis about and how they facilitated or made more difficult the first five years of adjustment. We also ask whether and how the world macroeconomy is likely to contribute to the solution of the debt problem in the next five years.

The paper starts with a conceptual framework and a review of the behavior of key macroeconomic variables in the past quarter of a century. From there we proceed to a discussion of the origins of the debt crisis, and to the adjustment period, 1982-1987. The following part reviews alternative scenarios for the period 1987-90 and their bearing on debt questions. We also ask what contribution to expect from commercial policies. The paper concludes pessimistically that for many debtors there is not a sufficient improvement to be expected from good performance of the world economy. This makes it necessary to find mechanisms tho make it possible to bring about a reversal of resource flows.

\section{EXTERNAL DEBT AND DEBT CRISIS: A FRAMEWORK}

In this part of the paper we set out a conceptual framework to discuss debt problems and the macroeconomic background to the debt cris is in 1979-82. 


\section{A Conceptual Framework}

The balance of payments and national income accounts provide a basic framework of analysis. The identities-relations which are true always and anywhere by accounting definition--are an objective conceptual setting.

There is a debt problem when a country cannot service its debt on the contracted schedule. Debt service difficulties may either be an ability to pay the principal of a maturing debt, as is the case for Colombia or Venezuela today, or an ability to pay both interest and principal. We focus here on debt difficulties of the more serious kind where interest cannot be paid. The reason is that difficulties in paying principal, when interest is regularly paid, should not present any difficulty since rolling over is a routine operation. The only reason difficulties with principal can become debt problems is if creditors wish to limit their regional exposure and hence insist on payment of principal even from those countries who are good debtors.

Focusing on interest payments, the current account of the balance of payments can be separated into two components: the noninterest current account (NICA) which includes trade in goods and in all services except interest payments on the external debt on the one hand, and interest payments on the other. Interest payments can be financed by noninterest surpluses or by net capital inflows:

$$
\begin{aligned}
& \text { Interest Payments }= \begin{array}{l}
\text { Noninterest Current } \\
\text { Account }
\end{array} \\
& \text { Inflow } \text { Net Capital } \\
& \text { Infow }
\end{aligned}
$$


The category "net capital inflows" includes four categories: reserve decumulation, direct foreign investment inflows, longterm portfolio inflows and short or medium term borrowing abroad which is often called "new money". In the debt problems of the interwar period or the period preceding 1914 new money took the form of a "funding loan". Today it is concerted or involuntary lending by the commercial bank creditors and multilateral institutions.

Table 1 shows these current account components for problem debtor countries in the $1978-87$ period. 1

Table 1 The Current Account Deficit and External Debt:

Countries With Recent Debt Servicing Difficulties (Billion \$)

\begin{tabular}{|c|c|c|c|c|}
\hline & $\begin{array}{l}\text { Noninterest } \\
\text { Cur.Account } \\
\text { (Resource Transfer) }\end{array}$ & $\begin{array}{l}\text { Interest } \\
\text { Payments }\end{array}$ & $\begin{array}{l}\text { Current } \\
\text { Account } \\
\text { Deficit }\end{array}$ & $\begin{array}{l}\text { External } \\
\text { Debt }\end{array}$ \\
\hline $\begin{array}{l}1978 \\
1979 \\
1980 \\
1981 \\
1982\end{array}$ & $\begin{array}{r}17.1 \\
10.1 \\
5.0 \\
20.2 \\
5.4\end{array}$ & $\begin{array}{l}14.8 \\
21.8 \\
34.3 \\
47.5 \\
57.5\end{array}$ & $\begin{array}{l}31.9 \\
31.9 \\
39.6 \\
67.7 \\
63.1\end{array}$ & $\begin{array}{l}242 \\
292 \\
356 \\
430 \\
494\end{array}$ \\
\hline $\begin{array}{l}1983 \\
1984 \\
1985 \\
1986 \\
1987\end{array}$ & $\begin{array}{l}-30.2 \\
-48.6 \\
-50.2 \\
-32.7 \\
-27.8\end{array}$ & $\begin{array}{l}52.1 \\
57.2 \\
53.6 \\
50.2 \\
45.7\end{array}$ & $\begin{array}{r}21.9 \\
8.6 \\
3.1 \\
17.5 \\
17.9\end{array}$ & $\begin{array}{l}514 \\
534 \\
553 \\
573 \\
586\end{array}$ \\
\hline
\end{tabular}

Source: IMF World Economic Outlook

Table 1 reveals the turn in the noninterest current account from a 
string of deficits until 1982 to a series of surpluses. In the period up to 1982 both interest payments and the noninterest deficit both need financing and hence are reflected in a rapidly rising debt. Since 1983 a large part of interest is paid by noninterest surpluses and hence the increase in debt is sharply reduced. But debt is still rising, reflecting the financing of the remaining interest payments not met by the surplus, and the financing of capital flight and reserve build-up.

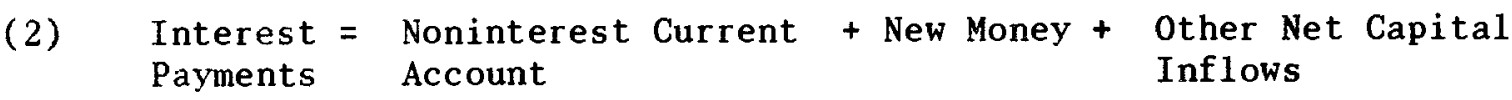

The category "other net capital flows" is typically very small. There is little room for reserve decumulation and longterm capital flows tend to be small. The only time other net capital flows assume importance is in the case of capital flight or, less frequent a repatriation of capital.

Table 2 Financing of Imbalances of Problem Debtors (Billion \$ U.S.)

\begin{tabular}{lccc} 
& $1979-82^{a}$ & $1983-86$ & 1987 \\
\hline Current Account Deficitb & 39.5 & 7.8 & 14.8 \\
$\begin{array}{l}\text { Non-Debt Creating } \\
\text { Inflows }\end{array}$ & 7.1 & 4.6 & 5.1 \\
Net Bor rowing & 49.4 & 11.6 & 16.3 \\
\hline
\end{tabular}

aperiod Average, b Deficit on goods, services and private transfers. 
The discrepancy between the current account on one side and the sum of net borrowing plus non-debt creating inflows (chiefly direct foreign investment and official aid) represents reserve changes and capital flight.

The noninterest deficit is often called the net resource transfer since it measures the net imports of goods and services (other than interest) over which a country acquires command. Noninterest deficits are the normal pattern for developing countries in which saving is low relative to investment. Noninterest deficits are the channel through which resources are transferred from rich to poor countries to support capital formation and growth in the developing world. Private and public lending forms the financial counterpart. Using the national accounts identities we can represent the financing of investment from the resource point of view as is done in (3) below.

$$
\text { Investment }=\text { Saving }+\begin{aligned}
& \text { Real Resource Transfer } \\
& \text { From Abroad }
\end{aligned}
$$

Table 3 shows the real resource transfers and the investment rates for Latin America. The Table brings out strikingly the decline in investment as a counterpart of the real resource transfer abroad. The shift in resource transfers is almost exactly matched by a decline in investment. 
Table 3 Resource Transfers and Investment (Percent of GDP)

$\begin{array}{lcc} & 1973-82 & 1983-85 \\ \text { Gross Investment } & 24.3 & 18.5 \\ & & 4.7 \\ \end{array}$

The essential distinction between pre-crisis and post-crisis is the turn of the net resource balance. Now debtor countries are making net resource transfers to creditor countries.

2. Debt Crises

Any debt crisis involves the inability of debtors to meet timely payments of interest and principal. Thus the gap between interest payments that are due and the noninterest current account (NICA) is the chief characteristic of a debt problem. Four factors then can be identified as leading to a debt problem:

- With an unchanged willingness to roll over debt and provide a given flow of new money, an increase in real interest rates raises the $f$ inancing requirement. The imbalance between new money requirements and credit voluntarily supplied brings about a debt crisis. 
- A deterioration in the noninterest current account, because of domestic macroeconomics or because of a worsening in the terms of trade or a fall in export demand, opens a financing gap,

- An increase in world inflation leads to an increase in nominal interest rates and hence to an early real amortization of the external debt. Al though real interest rates are unchanged there is a cash flow problem for debtors.

- With an unchanged interest rate and noninterest current account creditors decide that exposure is excessive and therefore 1 imit new money commitments and require that maturing principal be paid off.

We now proceed to identify the impact of world macroeconomic events on debtor countries. Specifically, given policies such as the real exchange rate and fiscal policy, how has the world macroeconomy been one of the factors in leading to the debt crisis, how has it influenced the evolution of the debt problems since 1982 and what implications can be anticipated from alternative scenarios of the world economy in the coming years? World interest rates, growth and commodity price trends are at the center of the discussion.

But a special interest attaches to their joint behavior. For example, if the interest payments a country owes increase but the noninterest deficit also increases. At the same time creditors become unwilling to increase their exposure. The financing equation then no longer adds up and something must give. When a debt crisis occurs and outright default or arrears are not the 
answer creditors are often coerced into involuntary lending and debtors undergo adjustment programs to turn their noninterest deficits into surpluses. Creditworthiness is to be reestablished. Now debtors have noninterest surpluses which finance the interest payments. But there may still be a part of interest payments financed by net capital inflows or "new money".

With this background in mind we now turn to the main world macroeconomic variables that had an influence in creating the debt crisis.

II. THE WORLD MACROECONOMY: AN OVERVIEW

Figures 1 to 4 highlight the chief external variables for debtor countries--the interest rate, the real interest rate, the real price of commodities and world economic activity. In Figure 1 we show the London inter bank offer rate for dollar deposits (LIBOR). The contribution of interest rates to the debt crisis is shown by the peak level of an interest rate in excess of 18 percent in late 1981.

The interest rate effects appear through two separate channels. One is associated with the level of nominal rates, given the real rate of interest. When higher inflation increases the nominal interest rate the effect on debtors is a shortening of the effective maturity of the debt. The real value of the debt is amortized at a faster pace. As a result debtors may experience liquidity problems.

Interest rates also, of course, hurt debtors when real rates increase. 
Libor (\%)

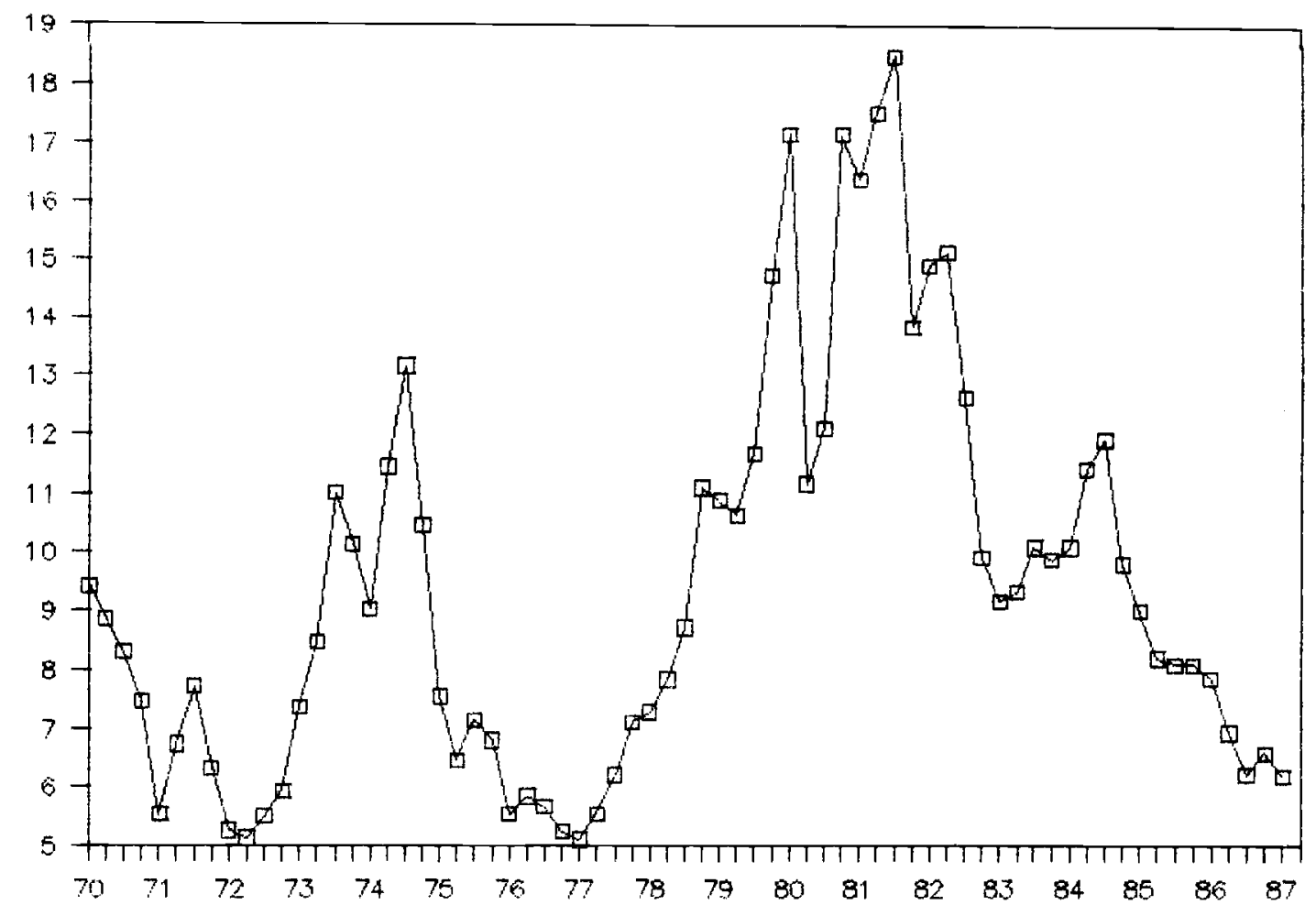

Figure 1 
In this context it must be decided in terms of which rate of inflation the real interest rate should be assessed and there is considerable difficulty in identifying the correct inflation rate. Alternative candidates might be the debtor countries' GNP deflator in dollars or the rate of inflation in world trade. We chose here the latter series and it is shown in Figure 2 together with the Libor rate. The behavior of the real rate is, of course, striking in that the sharp increase in nominal rates was accompanied by a falling level of prices in world trade. The combination implied that real interest rate facing debtor countries were much higher than 20 percent per year.

Figure 3 shows the real price of commodities. The series shown here is the IMF index of all (non-oil) commodities deflated by the export unit value of industrial countries. Commodity prices show a steady decline since their peak levels in 1973-74. By late 1986 they had fallen to only 40 percent of the peak level. But in the early 1980s, when the debt crisis first broke out, the real price of commodities did not show a dramatic deterioration. Commodity prices thus are not an immediate source of the crisis but they did become relevant later in raising the costs of adjustment for several debtor countries.

Figure 4 shows world economic activity measured by the index of industrial production in the industrialized countries. The behavior of the index is relatively smooth. The events of the early 1980s do not appear striking even though there was a decline of about 5 percent. 


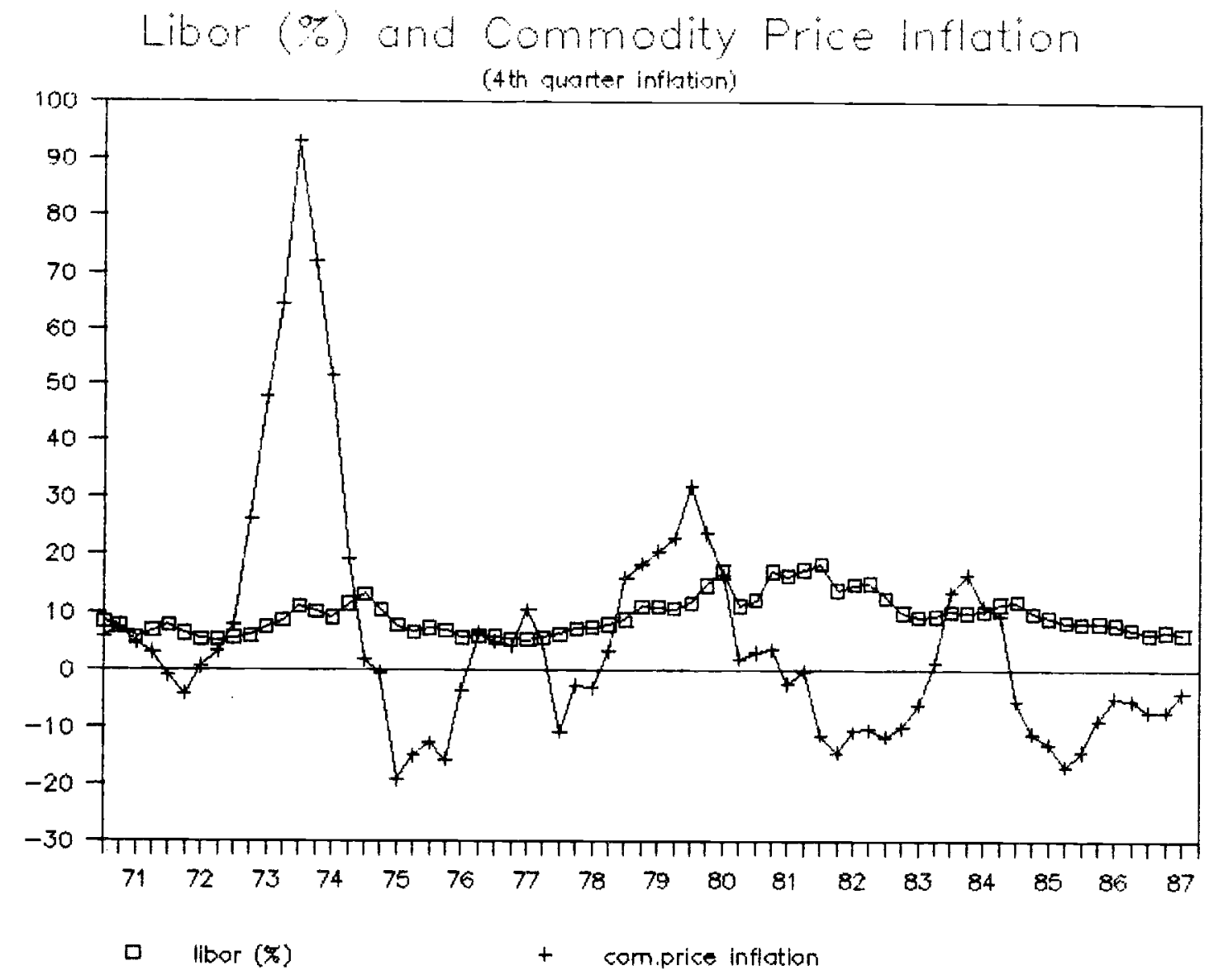

Figure 2 


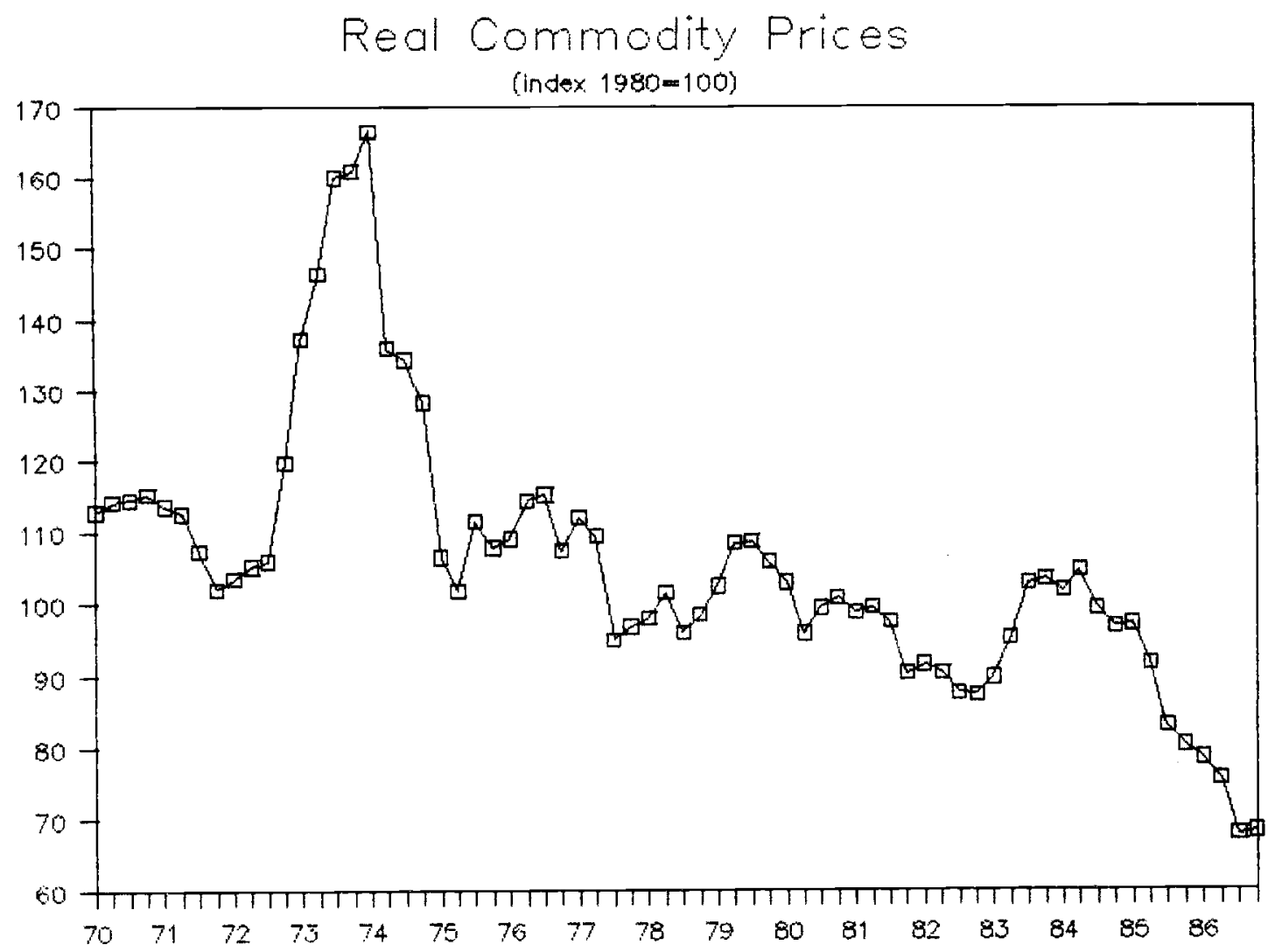

Figure 3 


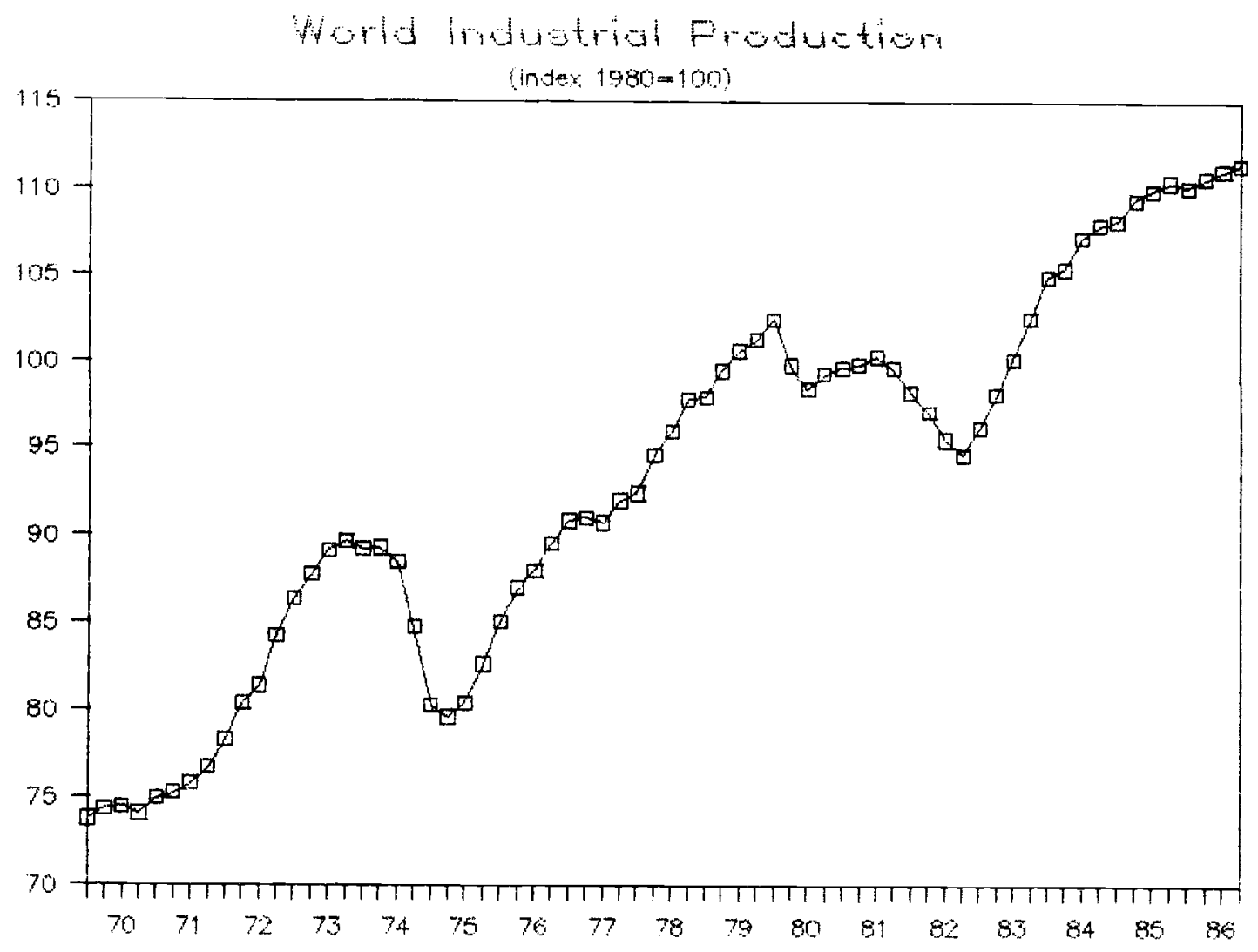

Figure 4 
Commodity Prices and Export Prices

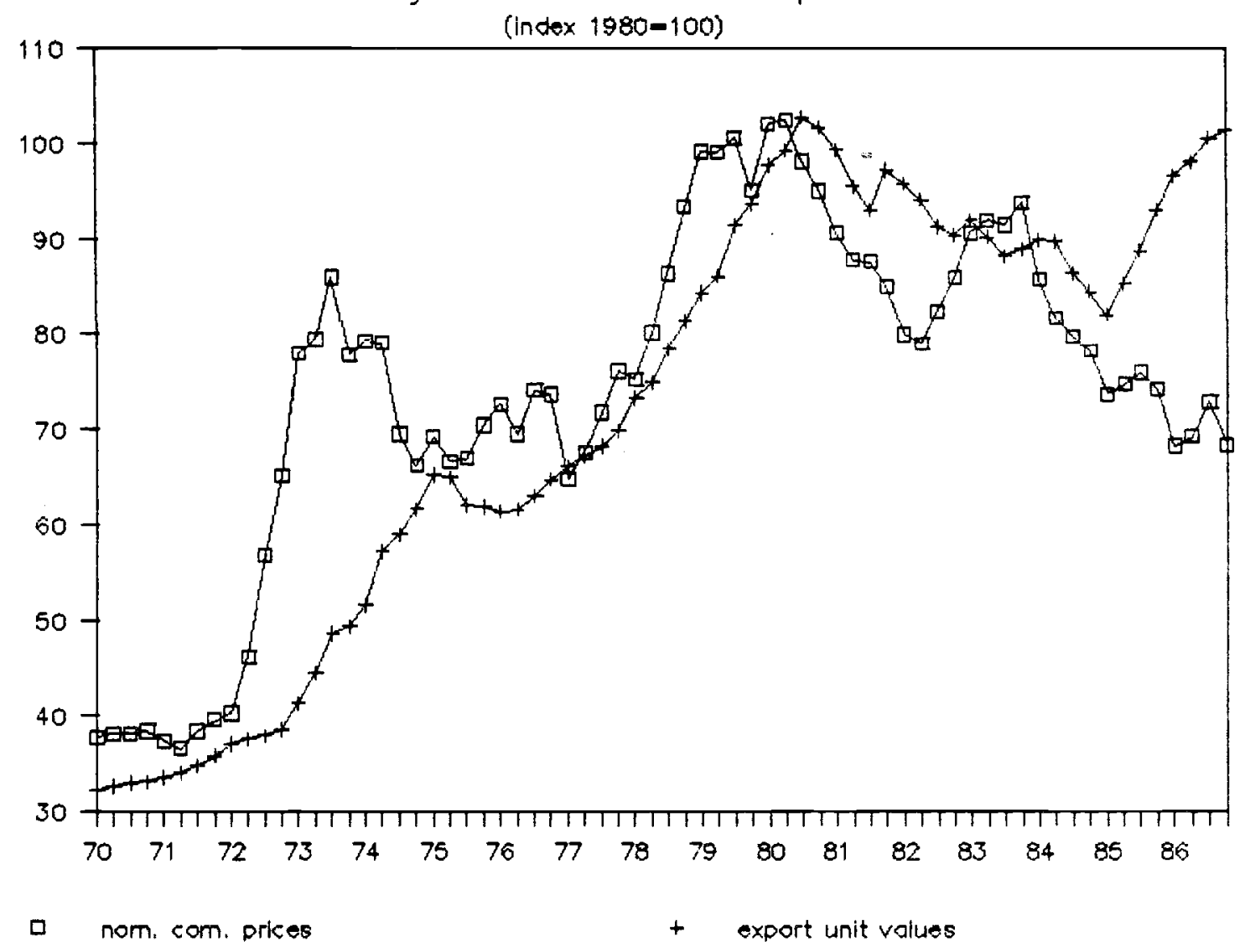

Figure 5 
Table 4 shows data for these aggregate indices. The Table reports the averages for the 1960s and 1970s and more detailed information on the period of the debt crisis.

Table 4 Aggregate World Macroeconomic Indicators

\begin{tabular}{|c|c|c|c|c|}
\hline & $\begin{array}{l}\text { Real Commodity } \\
\text { Prices }(1980=100)\end{array}$ & $\begin{array}{c}\text { Libor } \\
\%\end{array}$ & $\underset{\%}{\text { Inflation }}$ & $\begin{array}{l}\text { World Activityc } \\
(1980=100)\end{array}$ \\
\hline $\begin{array}{l}1960-69 \\
1970-79 \\
1980 \\
1981 \\
1982 \\
1983 \\
1984 \\
1985 \\
1986\end{array}$ & $\begin{array}{r}115 \\
115 \\
100 \\
96 \\
89 \\
98 \\
101 \\
88 \\
72\end{array}$ & $\begin{array}{r}5.2 \\
8.0 \\
14.4 \\
16.5 \\
13.1 \\
9.6 \\
10.8 \\
8.3 \\
6.9\end{array}$ & $\begin{array}{r}1.0 \\
11.4 \\
13.0 \\
-4.1 \\
-3.5 \\
-3.3 \\
-2.5 \\
-0.4 \\
13.7\end{array}$ & $\begin{array}{r}56 \\
86 \\
100 \\
100 \\
96 \\
99 \\
106 \\
110 \\
110\end{array}$ \\
\hline
\end{tabular}

a Measured in terms manufactures export prices of industrial countries.b Rate of inflation of industrial countries' unit export values. c Industrial production.

Source: IMF and Economic Commission for Latin America

In addition to interest rates, real commodity prices and economic activity in industrial countries a fourth external factor influences the noninterest current account. This is commercial policies in developing countries and their influence on market access and hence export performance. There are no good aggregate indicators of market access or of changes in market access. But there is also no suggestion that this factor would have been an important element in provoking the debt crisis. Of course, that does not mean that protectionism did not increase the costs and difficulties of debtor countries once the crisis had started. ${ }^{2}$ 
III. EXAMPLES OF THE EFFECT OF THE WORLD MACRO SHOCK

The broad overview of external factors gives little guidance to what was the incidence on individual debtors. Their common factor is only to be debtors and hence to be hurt by an increase in world interest rates. But even that exposure differs significantly across countries depending on the share of floating rate debt. At one end of the spectrum are poor debtors with most of their debt at concessional rates, at the other end are Brazil or Mexico for whom almost the entire debt has interest rates linked to market rates.

But differences in trade structure also matter and these imply differential effects among debtor countries of movements in commodity prices or in economic activity in industrial countries. Korea, for example, imports commodities while Brazil or Argentina are net commodity exporters. To investigate these differential impacts of the 1980 s external shock we now look at a number of cases of individual countries' experiences.

Brazil: Brazil exports commodities and also manufactures. In the early 1980s the country had just become a predominant exporter of manufactures. Of a total of $\$ 24$ billion in exports in 1981 nearly 38 percent were primary commodities (coffee, iron, soya, sugar) and the remainder manufactures. But much of manufactured exports had a high import content, as for example steel or orange juice. On the import side a striking 51 percent was oil. Of the external debt 
of $\$ 50$ billion, 80 percent was at variable interest rates and more than eighty percent was dollar denominated.

For Brazil, therefore oil prices and the world money market rate were the chief variables of interest. Being a net exporter of (non oil) commodities a decline in real commodity prices on balance would hurt. But the concentration in exports on coffee, orange juice soya and iron ore would be important to note.

The external balance problem, of course, originated in the oil price increase of 1978-79. 0 il imports increased from $\$ 4.5$ billion in 1978 to $\$ 11.4$ billion in 1981. This increase in the oil bill was automatically financed both in the budget and in the current account by the borrowing of the state enterprises in the world capital market.

The increase in world interest rates in 1979-81 added to the interest bill. In 1979 net interest payments amounted to $\$ 4.2$ billion. By 1981 they had risen to 9.2 billion and in 1982 to $\$ 12.6$ billion. At the end of 1978 the external debt was only $\$ 44$ billion and by the end of 1981 it had risen to $\$ 61$ billion and by the end of 1982 to $\$ 70$ billion. The increase in LIBOR from 8.9 percent in 1978 to 12,14 and 17 percent over the next three years added immediately a cunulative $\$ 7$ billion to the external debt. The combination of higher interest rates and higher oil prices "explains" almost the entire increase in debt between the end of 1978 and the end of 1981 . 
The fact that higher interest rates and higher oil prices explain the increase in debt can also be read to say that the failure to adjust to these external shocks, and the ability to borrow in world markets, meant that external debt was the means by which the country financed the impact of the external shock.

Mexico: The second oil price increase in 1978-79 provided an apparently sound basis on which to engage in a growth strategy. Petroleum export revenue increased from only $\$ 1$ billion in 1977 to $\$ 14$ billion in 1981 . But spending increased $f a r$ ahead of the increased revenues. The noninterest budget deficit, oil revenues notwithstanding, increased from 2 to more than 8 percent of GDP. The current account deteriorated even though oil revenues doubled every year. The strong domestic expansion, combined with a fixed exchange rate built up overvaluation. The extent of overvaluation at no point became as extreme as it had been in Chile or Argentina. But even so it led to significant deterioration in the trade balance and to massive capital flight.

Table 5 Mexico's Macroeconomy: 1977-81

\begin{tabular}{|c|c|c|c|c|c|c|}
\hline & 1977 & 1978 & 1979 & 1980 & 1981 & 1982 \\
\hline $\begin{array}{l}\text { Current Account Deficit } \\
\text { ( } \% \text { of GDP) }\end{array}$ & 2.3 & 3.1 & 4.1 & 4.4 & 5.8 & 3.8 \\
\hline $\begin{array}{l}\text { Real Exchange Rate } \\
(1980-82=100)\end{array}$ & 93 & 94 & 98 & 104 & 114 & 83 \\
\hline
\end{tabular}

Source: Morgan Guaranty and Banco de Mexico 
The capital flight was concentrated in the period 1981-82, in the final phase of the Portillo Lopez government. The deterioration in the external balance and the increasing difficulty in financing the deficit made it apparent that an exchange crisis was around the corner. Large wage increases led to an expectation of a sharp increase in inflation altogether incompatible with the maintenance of a fixed exchange rate. With no restrictions on capital flows there occurred then a massive flight into the dollar. In fact, the capital flight would have been much larger had it not been for the existence of domestic dollar deposits in the banking system. These Mex-dollar accounts absorbed a good part of the speculation, although their holders ultimately did much worse than those who bought the real thing. Estimates of the amount of capital flight from Mexico in 1978-82 differ. A recent study by Cuddington (1987) estimates a total of more than $\$ 25$ billion whereas Morgan Guaranty (1986) gives a higher number of $\$ 36$ billion. Whatever the exact number, there is no question that somewhere between 10 and 15 percent of GDP went abroad in these critical years. And the reason is exclusively mismanagement since, unlike in the case of Argentina or Chile, there was no deterioration in external conditions until interest rates increased. On the contrary, the oil price increase had provided an extraordinary gain in real income and a potential improvement in the external balance. 
Argentina: The Argentinian external; debt problems were largely due to a mismanagement of the exchange rate. The overvaluation of $1978-81$, combined with the liberalization of capital flows, brought about massive capital flight.

Table 6 shows the basic data. Note the large real appreciation in 1978-80 and the terms of trade improvement up to 1981. The oil price increase which was important for Mexico, Brazil or Korea had no effect on Argentina's terms of trade since the country is selfsufficient in oil.

Table 6 Argentinan Macroeconomic Variables: 1978-82

\begin{tabular}{|c|c|c|c|c|c|}
\hline & 1978 & 1979 & 1980 & 1981 & 1982 \\
\hline Debt/GDP & 23.9 & 30.2 & 37.3 & 48.1 & 60.3 \\
\hline $\begin{array}{l}\text { Current Account } \\
\text { as \% of GDP }\end{array}$ & 4.0 & -1.0 & -7.6 & -7.4 & -3.8 \\
\hline Terms of Trade & 84 & 88 & 100 & 114 & 99 \\
\hline Real Exchange Rate & 65 & 84 & 100 & 70 & 49 \\
\hline
\end{tabular}

Index $1980=100$

The increase in external debt in Argentina far exceeds the cumulative current account. Therefore interest rate and terms of trade shocks cannot account for the major part of the debt problem before 1981. On the contrary, overvaluation and capital flight are the chief problems in this period. As we shall see below this is no longer the case after 1982 when the terms of trade deterioration becomes an important issue. 
Korea: As an oil importer Korea experienced a major deterioration in the terms of trade. The interest rate shock reinforced the external balance deterioration. But even so, by 1982 the external balance had already turned around an the deficit had become more moderate. In part this is a reflection of the real depreciation which restored competitiveness in the years following the crisis of 1980. In part it reflects a successful policy of exporting labor services to the oilproducing countries.

Table 7 Korean Macroeconomic Variables

\begin{tabular}{llcccc} 
& 1978 & 1979 & 1980 & 1981 & 1982 \\
\hline $\begin{array}{l}\text { Terms of Trade } \\
\text { Net Exports of Goods }\end{array}$ & 118 & 115 & 100 & 98 & 102 \\
$\begin{array}{l}\text { and Nonfactor Services } \\
\text { Net Factor Payments }\end{array}$ & -3.0 & -7.3 & -7.8 & -5.4 & -2.6 \\
From Abroad b & -1.3 & -1.5 & -3.3 & -4.0 & -4.1 \\
\hline
\end{tabular}

a Index $1980=100$.b Percent of GDP, National Income Accounts

Chile: The Chilean case, just as that of Argentina and Mexico, reflects until 1982 primarily a mismanaged exchange rate rather than a predominance of external shocks. As shown in Table 8 the terms of trade initially improve and the deterioration of the external balance is above all due to the extraordinary overvaluation. 
Table 8 Chilean Macroeconomic Variables

\begin{tabular}{lccccc} 
& 1978 & 1979 & 1980 & 1981 & 1982 \\
\hline Terms of Trade & 94 & 106 & 100 & 86 & 77 \\
Real Exchange Rateb & 91 & 100 & 120 & 136 & 122 \\
Trade Balancec & -0.4 & -0.4 & -0.7 & -2.7 & 0 \\
Current Accountc & -1.1 & -1.1 & -2.0 & -4.7 & -2.3 \\
\hdashline Index 1980=100, bIndex 1980-82=100, c Bilion \$ & & \\
Source: CIEPLAN and Morgan Guaranty &
\end{tabular}

Only in 1981-82 do international factors take over and deteriorate the external balance via increased interest burdens. In 1981 the overvaluation and the external factors combine to yield record deficits. But by 1982 exchange rate adjustment and domestic restraint already compensate on the trade side and the current account deterioration only reflects increased interest rate burdens.

Conclusion: The examples illustrate that external factors were by no means the only factor in the debt crisis. On the contrary, domestic policies were an important and often main influence in bringing about a large accumulation of debt. External factors reinforced the impact of these debts in 1981-82 via the interest rate shock. 


\section{THE PERIOD 1982-1987}

In this part we investigate how the world macroeconomy influenced the debt problem in the period since 1982. We start with a review of the beliefs of 1982, namely that favorable trends in the world economy would significantly facilitate debt service. From there we go to a more detailed consideration of the actual evolution of the world economy to ask whether world macroeconomic conditions in fact facilitated debt service or added to the burdens.

\section{The Beliefs of 1982}

When in 1982 Mexico, and shortly afterwards a host of Latin American countries, encountered acute debt service problems the process of concerted or involuntary lending started. The basic philosophy of that process had three ingredients:

- To assure an ultimate return to voluntary lending it was essential that debtor countries should service their debts to the maximum extent possible, on commercial terms and without significant concessions other than in respect to the maturity of the debt principal.

- Adjustments in debtor countries, specifically in the budget and exchange rates, would go far to bringing about a swing in the noninterest balance so as to service debt.

- The world macroeconomy would make a substantial contribution in reducing the burden of debt servicing. From the vantage point of 1982 the 
macroeconomy could only improve. Debtor countries could anticipate higher growth in demand for their exports, lower interest rates, and improving terms of trade.

The question of adjustment in debtor countries is beyond the scope of this paper and has been amply dealt with elsewhere. ${ }^{3}$ The issue of interest here is the contribution of the world macroeconomy. Certainly in 1982 the outlook must have been favorable.

- The world economy was in the deepest recession since the $1930 \mathrm{~s}$. In the recovery period there had to be, accordingly, an expectation of growth significantly above trend. This growth would bring about two results. First it would mean an increase in demand for manufactures exports from debtor countries. Second it would translate into a cyclical upturn of real commodity prices. These stylized facts were quite beyond doubt, given the ample empirical evidence on the cyclical behavior of real commodity prices and export volumes. 4

- In respect to interest rates the outlook also had to be outright favorable. The short term interest rate was at record high levels in American history. These high levels of interest rates were an immediate result of a deliberate attempt to use monetary policy to stop the sharply accelerating U.S. inflation of the late 1970s and early 1980s. With the success of disinflation interest rates would decline and hence the extraordinary debt service burdens of 1982 would come down. 
- Even though the dollar had appreciated already for more than a year there was not much discussion on this issue. The reason was presumably that dollar appreciation started from a very low point so that overvaluation was not yet a relevant notion. Nor was there an expectation of significant further appreciation. Discussion of a contribution of dollar depreciation to the debt crisis only occurred over the next three years as dollar overvaluation became increasingly apparent.

The framework for analysis of debt problems became rapidly the Avromovic-Cline model of debt dynamics, focusing on the ratio of debt to exports, b. The key question was whether the evolution of the world macroeconomy made declining ratios of debt to exports likely. The evolution of the debt-export ratio over time (b) can be developed in term of several determinants, specifically interest rate (i), the growth rate of export prices $(p x)$ and the growth rate of export volume $(x)$ :

$$
\dot{b}=b\left(i-p_{x}-x\right)-v ;
$$

where $\mathrm{v}$ denotes the noninterest current account surplus as a ratio of exports. Equation (4) highlights that debt problems in the sense of an ever rising debt to export ratio. Such a course is unlikely if the real interest rate, defined as nominal rates less the rate of inflation of export prices, is less than the growth rate of export volume and if there is a noninterest 
current account surplus. Table 9 shows the longterm averages for some of these variables to use as a benchmark.

Table 9 Longterm Average Growth Rates: 1969-78

\begin{tabular}{llccc} 
& Libor & Export Prices & Export Volume & Debt Ratio \\
\hline Asia & 7.8 & 10.1 & 10.8 & 75.7 \\
Western Hem. & 7.8 & 13.9 & 1.7 & 197.7 \\
Problem Debtors & 7.8 & 12.1 & 2.3 & 164.3
\end{tabular}

a Ratio of debt to exports of goods and services in 1979 Source: IMF

With the data for problem debtors, and assuming a spread over Libor of 2.2 percent we observe that the debt-export ratio would be declining unless there was a noninterest current account deficit in excess of 7 percent of exports. Of course, in 1978-82 the deficits were in fact much larger.

The expectation of declining nominal interest rates and cyclically rising nominal and real export prices for debtor countries implied an expectation of $10 \mathrm{w}$ real interest rates. Recovery and sustained growth in the industrial countries was expected to translate into significant growth in export volumes.

Adjustment in debtor countries, both in terms of expenditure cutting and real depreciation, was expected to translate into significant export growth and into an increased noninterest current account surplus. Thus for every element in the debt dynamics equation a favorable scenario could easily be predicted. And if there was any pessimism on real interest rates and growth 
in export volume, the fact of non-interest current account surpluses provided the necessary leeway to make a trend reduction in debt burdens plausible. Cline (1983) in particular expressed the view that the debt problem was largely under control. Using simulations for the major debtor countries, and assuming alternative scenarios for the world economy he showed that for most debtor countries there was an expectation of declining debt-export ratios. Moreover, the gain in creditworthiness implied by a reduced debtincome ratio in several cases could be accompanied by significant growth in the debtor countries. Brazil, for example, could in Cline's simulations achieve both an average growth rate of 6 percent and a reduction in its debtexport ratio. The $\mathrm{Cl}$ ine analysis rightly emphasized the crucial role of oil prices in determining the relative performance of Mexico and Brazil. With the assumption of declining oil prices Mexico was a problem country and Brazil's prospects were relatively bright.

Table 10 shows a mediumterm scenario developed by the IMF in 1982 as well as the actual outcome for the key variables. The IMF scenario assumed a strong internal adjustment in the debtor countries, continued inflation fighting in the industrial countries, a constant real price of oil at the 1982 level and a sharply declining real Libor rate. Table 10 reports three scenarios: The base 1 ine scenario is labelled A, scenario $B$ is pessimistic and hence imposes extra adjustment requirements on debtors, and scenario $\mathrm{C}$ is optimistic. The optimism and pessimism are judged in terms of the growth- 
inflation mix in industrial countries. There was apparently no recognition at the time of the real interest rate consequences of rapid disinflation and of the U.S. monetary-fiscal mix. The other respect in which the scenario is interesting is that there was a quite explicit confidence that current account imbalances could be financed.

Table 10 The 1982 IMF Scenarios for Non-0il Developing Countries (Average annual rates for $1984-86$ except as noted)

\begin{tabular}{|c|c|c|c|c|}
\hline & A & B & $\mathrm{C}$ & Actual \\
\hline Industrial Country Growth & 3.2 & 2.2 & 4.3 & 3.1 \\
\hline Industrial Country Inflation & 5.5 & 8.0 & 4.5 & 3.8 \\
\hline Real Libor Ratea & 2.0 & 2.0 & 2.0 & 5.4 \\
\hline $\begin{array}{l}\text { Net 0il Importers } \\
\text { Export Volume } \\
\text { Terms of Trade }\end{array}$ & $\begin{array}{r}7.6 \\
-0.5\end{array}$ & $\begin{array}{r}5.9 \\
-1.7\end{array}$ & $\begin{array}{l}9.2 \\
0.9\end{array}$ & $\begin{array}{l}8.1 \\
0.7\end{array}$ \\
\hline $\begin{array}{c}\text { Net } 0 i 1 \text { Exporters } \\
\text { Export Volume } \\
\text { Terms of Trade }\end{array}$ & $\begin{array}{l}5.0 \\
0\end{array}$ & $\begin{array}{r}4.0 \\
-1.0\end{array}$ & $\begin{array}{l}6.0 \\
1.0\end{array}$ & $\begin{array}{c}3.6 \\
-10.0\end{array}$ \\
\hline $\begin{array}{c}1986 \text { Current Account } \\
\text { Net Oil Importers } \\
\text { Net Oil Exporters }\end{array}$ & $\begin{array}{l}-13.7 \\
-20.6\end{array}$ & $\begin{array}{l}-19.4 \\
-27.0\end{array}$ & $\begin{array}{r}-9.0 \\
-17.5\end{array}$ & $\begin{array}{r}-1.4 \\
-16.8\end{array}$ \\
\hline
\end{tabular}

2. The Actual Experience Since 1982 
The actual outcome shown in Table 10 differs from the IMF scenario in the following respects:

- Real interest rates continued to be far higher than expected. The U.S. monetary-fiscal mix this ha strong implications for the performance of countries with high debt ratios and a high ratio of floating rate debt.

- The real oil price fell dramatically and hence the relative performance of net oil exporters was due more to their adjustment efforts then to favorable terms of trade.

- The assumption that debtor countries could afford to run significant current account deficits was overly optimistic. Financing constraints in fact limited these deficits.

Table 11 shows further details on nominal interest rates, real oil prices and on commodity prices which were only addressed in the terms of trade category of Table 10 .

Table 11 Commodity Prices, 0il Prices and Interest Rates (Average Annual Percent)

\begin{tabular}{lccc} 
& Commodity Prices & Interest Rates & Real 0 il b \\
$1969-78$ & 9.8 & 7.8 & \\
$1980-1982$ & -4.1 & 14.8 & 100 \\
$1983-1986$ & -3.4 & 8.9 & 80 \\
\hline
\end{tabular}

a Libor bDeflated by manufactures prices, Index 1980-82=100 Source: IMF

Nominal interest rates did, indeed, decline significantly from their 
peak levels and OECD growth showed somewhat above the 3 percent threshold that had been set as a benchmark for solving debt problems. The significant difference from the 1982 outlook was in respect to commodity prices. Rather than showing a recovery in nominal and real terms they in fact continued to decline. The decline was so significant that in 1986 they were at a lower level than anytime in the preceding quarter of a century as already shown in Figure 3 above. In nominal terms they had fallen back to the level of 1977.

Creditworthiness: The belief that debt and debt service ratios would decline has not in fact been borne out as shown in Table 12. On every measure of creditworthiness debtor countries today look worse than they were in 1982 , excepting the debt service ratio. The reduction in interest rates since 1982 clearly helped reduce the service ratio as did the longterm restructuring of debts. But even though there is a marginal reduction in the debt service ratio the extent of decline falls by short of the 1982 expectations.

Table 12 The Deterioration of Creditworthiness (Percent)

\begin{tabular}{lccccccccc} 
& \multicolumn{3}{c}{ Debt/GDP } & \multicolumn{3}{c}{ Debt/Exports } & \multicolumn{2}{c}{ Debt Service } \\
& 1978 & 1982 & 1986 & 1978 & 1982 & 1986 & 1978 & 1982 & 1986 \\
\hline Al1 Debtor LDCs & 26 & 34 & 40 & 132 & 151 & 180 & 14 & 20 & 22 \\
Problem Debtors & 31 & 43 & 49 & 180 & 254 & 282 & 28 & 40 & 38
\end{tabular}

Source: IMF World Economic Outlook 
Favorable conditions in the world economy and the beneficial effects of adjustment programs on the part of debtors were expected to show in time an improvement in credit worthiness sufficient to warrant a return to voluntary lending. That remains the expectation, But the process is not on schedule. Abstracting from the oil shock, which improved the situation of Korea and Brazil while dramatically worsening that of Mexico, there has been as yet no improvement as dramatic as had been anticipated. Standard indicators of creditworthiness such as the ratio of debt to GDP or debt to exports have in fact worsened since 1982 .

The return of voluntary lending was predicated on countries restoring their credit standing. While creditworthiness is a broad and vague idea, the operational concept was a reduction of ratios of debt to GDP and debt to exports. Table 12 shows that since 1982 creditworthiness measured by these benchmark ratios has worsened or at least not deteriorated, making the current adjustment effort of debtor countries entirely openended.

The Cline Projections: While the preceding discussion focuses on group of countries it is also of interest to see how forecasts fared in specific country cases. The analysis by $\mathrm{Cline}$ (1983) provides that possibility for the year 1985. Table 13 shows the results for Argentina, Brazil and Mexico. 
Table 13 Cline Projections and Actual 1985 Outcomes (Billion \$)

\begin{tabular}{|c|c|c|c|c|c|c|}
\hline & \multicolumn{2}{|c|}{ Argentina } & \multicolumn{2}{|c|}{ Brazil } & \multicolumn{2}{|c|}{ Mexico } \\
\hline & Cline & Actual & Cline & Actual & Cline & Actual \\
\hline Exports & 10.4 & 8.4 & 29.5 & 25.6 & 23.6 & 21.9 \\
\hline $\begin{array}{c}\text { Imports } \\
0 \mathrm{i} 1\end{array}$ & 6.4 & 3.8 & $\begin{array}{r}18.2 \\
7.0\end{array}$ & $\begin{array}{r}13.2 \\
5.7\end{array}$ & 16.0 & 13.5 \\
\hline Interest & 6.2 & 5.3 & 13.0 & 9.6 & 10.7 & 9.9 \\
\hline
\end{tabular}

Source: Cline (1984) and various government publications.

Three points stand out in these comparisons. First, that export revenues fall short of those predicted by $\mathrm{Cline.} \mathrm{Second,} \mathrm{that} \mathrm{import} \mathrm{spending}$ is much lower than $\mathrm{Cl}$ ine had predicted. Third, that interest payments are somewhat lower than predicted by $\mathrm{Cline.} \mathrm{Note,though,} \mathrm{that} \mathrm{the} \mathrm{Brazilian}$ current account surplus of 1985 was correctly predicted by Cline. of course, by 1986 the differences are much more pronounced because of the vast influence of the decline in oil prices from $\$ 28$ to $\$ 15$ per barrel.

Extreme Cases: There are some examples of countries who are outlines in the adjustment period since 1982. On one side countries who are predominant exporters of commodities and borrowers primarily from official sources. They would experience the large and continuing decline in commodity prices without the advantage of reduced interest burdens. 
Among the countries that come to mind in this category there is certainly Bolivia. Interest payments are to the extent of 70 percent at fixed rates so that the fall in world interest rates did not bring major benefits. But the terms of trade deteriorated over the period 1981-1986 by 14 percent. The value of exports declined in 1984-86 cumulatively by 40 percent!

The most striking improvement in the external debt position in the adjustment period is probably that of Korea. Korea benefited from every one of the factors characterizing the 1982-87 period: lower commodity prices, lower oil prices and lower interest rates. Each of these factors exerts a very significant impact on the external balance and hence the combined effects--in conjunction with an aggressive exchange rate policy--produced a dramatic improvement in the external balance. The shift in the current account represents nearly 10 percent of GNP by 1986 and is still widening.

V. THE OUTLOOK

In this section we ask whether there are important shifts in the world macroeconomic outlook, and in the outlook for trade policies and the capital market, that promise to help overcome the debt problem or threaten to make its solution much more difficult. On the side of macroeconomics there is certainly a possibility of quite different scenarios depending on the way in which the U.S. budget problem is solved and the response of interest rates and the dollar to budget cuts when they do take place. 
1. The 1987 IMF Scenario

A useful framework of reference economic outlook is the 1987 IMF medium-term scenario shown in Table 14. The central assumption of this scenario is a continued high real interest rate level compensated by sustained growth in the world economy and in debtor country exports. There is an expectation of moderately rising real oil prices and no change in the terms of trade.

Table 14 The 1987 IMF World Economic Outlook

\begin{tabular}{|c|c|c|c|}
\hline & 1987 & 1988 & $1989-91$ \\
\hline \multicolumn{4}{|l|}{ Industrial Countries } \\
\hline Growth & 2.3 & 2.8 & \\
\hline Real LIBOR & 3.6 & 3.0 & \\
\hline GDP Deflator & 2.9 & 3.4 & \\
\hline
\end{tabular}

World Economy

$\begin{array}{lrrr}\text { Manufactures Prices } & 11.0 & 3.1 & 3.0 \\ \text { Oil Prices } & 8.7 & 3.1 & 3.0 \\ \text { Non-oil Commodities } & -4.9 & 5.1 & 4.7\end{array}$

Problem Debtors

$\begin{array}{lrrr}\text { Real GDP } & 4.4 & 4.7 & 5.0 \\ \text { Terms of Trade } & -2.1 & -1.0 & - \\ \text { Export Volume } & 5.4 & 5.9 & 5.6 \\ \text { Import Volume } & 2.5 & 3.6 & 5.7 \\ \text { Current Account a } & -1.5 & -0.6 & -0.6 \\ \text { Interest Payments }{ }^{\text {a }} & 6.3 & 5.9 & 5.4\end{array}$

Lat in America

\begin{tabular}{lrrr} 
Real GDP & 3.3 & 4.7 & 4.8 \\
Terms of Trade & -4.7 & -0.6 & 0.2 \\
Export Volume & 0.1 & 7.2 & 5.1 \\
Import Volume & -0.8 & 2.4 & 5.4 \\
Current Accounta & -14.3 & -9.3 & -5.7 \\
Interest Payments & 25.3 & 23.1 & 20.5 \\
\hline
\end{tabular}

apercent of exports of goods and services

Source: IMF World Economic Outlook. April 1987 
In terms of equation (4) above the IMF outlook places major reliance on continued large non-interest current account surpluses and on export volume growth to help contain or reduce debt problems. The fact that the scenarios allow for growth in imports at roughly the same rates as those of exports is possible because the starting point is a large noninterest surplus. Hence maintaining equal growth rates, with unchanged terms of trade, assures that noninterest surplus are maintained. In other words the IMF assumes that in the period to 1991 problem debtors will continue to make real resource transfers to their creditors at present rates.

\section{U.S. Adjustment: Implications for Debtor Countries}

It is interesting to go beyond the IMF outlook and focus on the central development in the world economy in the next few years, namely U.S. adjustment of the twin deficits. Table 15 shows the U.S. macroeconomic data for the recent years.

Table 15 The U.S. External Balance and Net Investment Position (Billion \$ except as noted)

\begin{tabular}{|c|c|c|c|c|c|}
\hline & 1982 & 1983 & 1984 & 1985 & 1986 \\
\hline Int'1. Investment Position & 136.2 & 88.5 & 4.4 & -107.4 & -238 \\
\hline $\begin{array}{c}\text { Current Account } \\
\text { Total } \\
\text { Non-Interest } \\
(\% \text { of GNP) }\end{array}$ & $\begin{array}{r}-9.2 \\
-28.1 \\
-0.9\end{array}$ & $\begin{array}{r}-45.6 \\
-37.0 \\
-1.1\end{array}$ & $\begin{array}{r}-112.5 \\
-131.3 \\
-3.5\end{array}$ & $\begin{array}{r}-124.4 \\
-149.6 \\
-3.7\end{array}$ & $\begin{array}{r}-147.7 \\
-170.6 \\
-4.1\end{array}$ \\
\hline Budget Deficit ( $\%$ of GNP) & -4.1 & -5.6 & -4.9 & -5.1 & -4.6 \\
\hline
\end{tabular}

Source: U.S. Department of Commerce, Federal Reserve and IMF 
Table 17 Consequences for Debtors of U.S. Adjustment Scenarios

Soft Landing

Hard Landing

Trade Restrictions Moderate Trouble Debt Default

No Trade Restrictions Major Improvement Moratoria

Table 17 shows strikingly that the debt problem today remains wideopen. Sustained U.S. growth with low real interest rates and unimpaired market access means debt problems will become significantly smaller. Continued ability to sell in the U.S. market, higher real commodity prices which come with dollar depreciation and lower real interest rates all combine to a scenario favorable for debtors. Of course, the counterpart of U.S. external balance improvement in this case is a worsening of the net exports of Europe and of Japan. But lower real interest rates have a self-correcting property in that debtor countries can reduce their noninterest surplus and yet improve their creditworthinesss. This feature means that there is not necessarily a conflict between U.S. and debtor country objectives. When debtor countries argue for the need to reduce U.S. deficits they presumably have this scenario in mind. 
The other extreme scenario is a hard landing with trade restrictions. The consequences are obvious: Recession and high real; interest rates move debt service problems far beyond what debtor countries an be expected to make up for by domestic adjustments. Trade restrictions further worsen their ability to service debts. The almost certain consequence would be 1930 style debt defaults or indefinite suspension of debt service.

World growth and real interest rates are central in judging the impact of alternative scenarios for debtor countries. On the side of growth U.S. fiscal adjustment will tend to reduce growth in the world economy. If U.S. output growth is sustained this will mean that real depreciation sustains net exports and that accordingly foreign growth will tend to be less. It is very unlikely that Europe and Japan will provide an expansion in demand sufficient to keep world output growth constant. Thus on the growth side the expectation must be that the performance of the past few years cannot be sustained. But on the interest rate side there may be a favorable development. if the U.S. does adjust the budget and sustains growth by lower interest rates the dollar will depreciate and this is likely force Europe and Japan into interest rate reductions even if that threatens monetary discipline.

The impact of interest rates on debtors current account balances is, of course very significant. Table 17 shows estimates of the impact on various Latin American countries of a 2.5 percentage point reduction in interest rates. Table 18 shows that the impact on individual debtor countries will 
depend both on their debt ratios and on the fraction of debt that is at floating rates.

Table 18 Interest Saving from a 2.5 Percentage Point Fall in Interest Rates (Billion \$ and Percent of Imports of Goods and Services)

\begin{tabular}{llr} 
& $\$ B i 1$ ion & Percent of Imports \\
\hline Latin America & 6.0 & 7.8 \\
Mexico & 2.0 & 10.5 \\
Venezuela & 0.5 & 5.7 \\
Bolivia & 0.025 & 3.5 \\
Chile & 0.4 & 9.4 \\
Argentina & 0.8 & 15.7 \\
Brazil & 1.7 & 10.3 \\
Peru & 0.14 & 5.1
\end{tabular}

Source: ECLA

The impact of interest rate changes on import availability is very significant for Mexico, Argentina and Brazil, who are the large borrowers from commercial banks. For Latin America at large a 2.5 percent reduction interest rates would amount to a resource saving of nearly 8 percent of total imports. Hence the importance to debtors of the monetary policies that accompany the correction of the U.S. deficit.

Trade barriers might not be applied uniformly across U.S. trading partners. They might be applied only to industrial countries, specifically Japan, or only to current account surplus countries, rather than to countries with bilateral surpluses. For debtors the implication here is that an improvement in debt service ability of countries like Mexico or Brazil might 
be paid for by extra restrictions on Korea or Taiwan. Thus developing countries as a group might experience an improvement while specific countries 1 ike Korea bear the burden.

There is another way of looking at debtor countries and U.S. adjustment. Suppose that the U.S. in fact achieved a $\$ 100$ billion reduction in the external deficit. Assume also that this had as a counterpart a $\$ 20$ billion improvement in the U.S. bilateral trade balance with Latin America. How can Latin America experience a $\$ 20$ billion deterioration in the external balance? There are only two ways: much lower interest rates or significant extra financing. Thus any hard landing scenario without default of necessity involves a dramatic change in financing availability which is not apparent today.

The focus on the U.S. adjustment problem throws a very different light on the 1 inks between world macroeconomics and debt problems. It suggests that the steady IMF scenario conceals that there is either good or bad news, but probably not the balanced no-news outlook implicit in Table 14. of course, it is possible that U.S. adjustment is a matter of the more distant future, In that case the IMF scenario would be more appropriate for the nearterm. But there would inevitably be an adjustment some time and that might be more nearly of the hard landing variety.

Is there a chance that debt problems will be solved in some other fashion by the world macroeconomy? Here one would look to a pattern of terms 
of trade, interest rates and inflation of the 1970-73 variety. Since the U.S. is already at full employment continuing depreciation and monetary accommodation, without fiscal contraction, will inevitably raise inflation while sustaining growth. This policy setting would ease debt problems significantly. The only question is whether the process of sliding gently into the soft landing option, with a few years delay, can in fact be achieved. The monetary authorities would have to be sufficiently accommodating and impervious to inflation, and asset holders would have to be patient, sitting out dollar depreciation without a stampede. This does not seem to be a high probability scenario.

\section{The Commodity Price Problem}

The final point to raise concerns the longterm behavior of commodity prices. Figure 6 shows a longterm time series for the real price of commodities. Although the exact comparisons across periods is impaired by the fact that these data are spliced from different series the basic point is very striking. 5 Commodity prices in the mid-1980s have reached the lowest level in real terms since the great depression.

Table 19 The Real Price of Commodities: 1950-1986

(Index 1980=100, period averages)

\begin{tabular}{llll}
$1950-54$ & 124 & $1975-79$ & 104 \\
$1955-59$ & 113 & $1980-84$ & 94 \\
$1960-64$ & 106 & 1985 & 85 \\
$1965-69$ & 108 & 1986 & 69 \\
$1970-74$ & 115 & & \\
\hline
\end{tabular}

Source: IMF (1987b) 
Figure 6

Longterm Trends of Real Commodity Prices

(Index $1980=100$ )

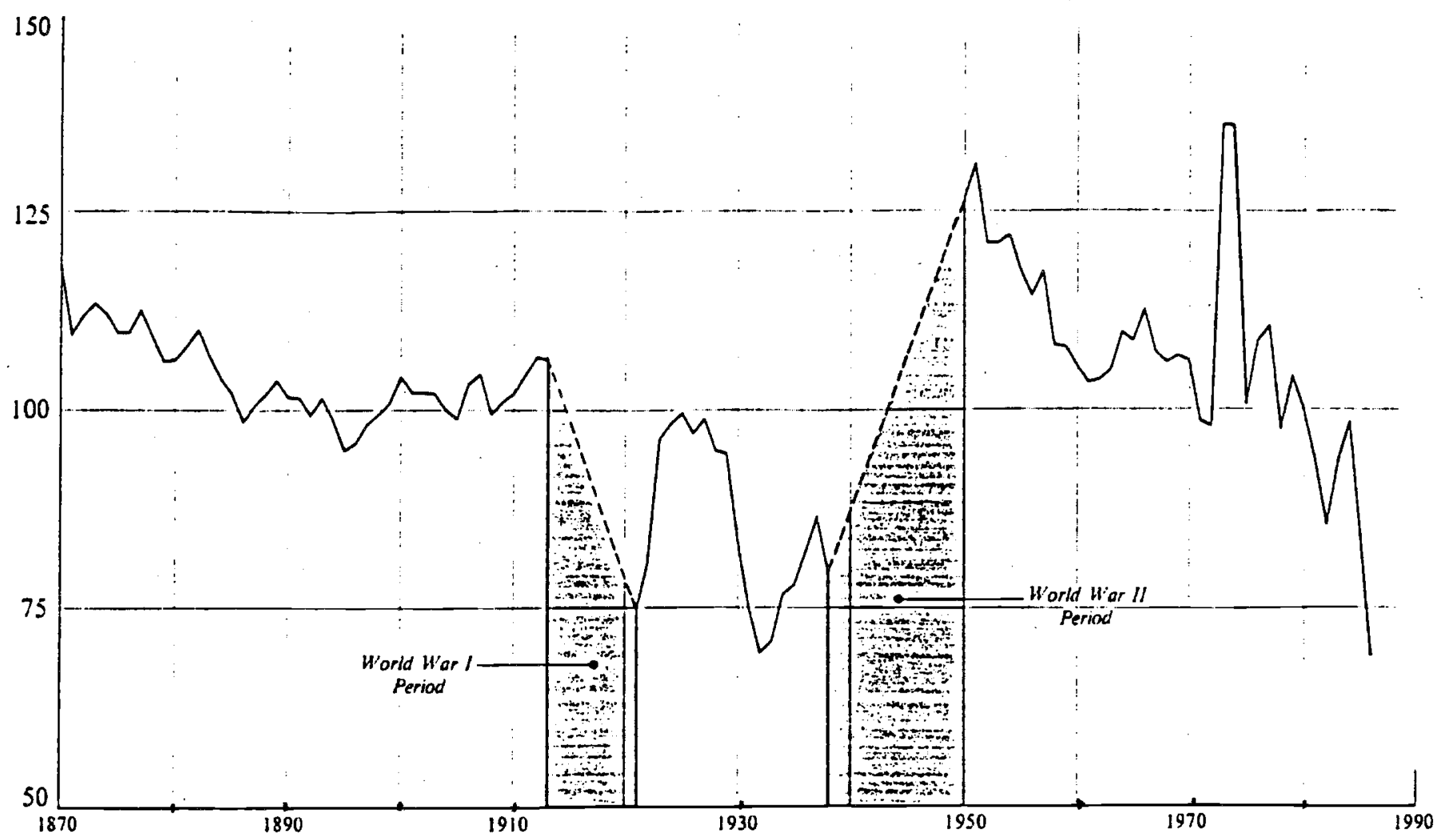

Source: IMF (1987) 
Several factors explain this low level of commodity prices. The high level of real interest rates is one and, until 1985-86 the high level of the dollar was another one. But these factors are not sufficient to explain the large decline as discussed in Dornbusch (1985). Substitution toward resource saving technologies on the demand side, real depreciation and hence increased levels of output at given world real prices are other factors. Capacity expansion in many producing countries are further factors that reduce real prices. Finally, for agricultural commodities government support policies in industrial countries have played an important role.

But this large decline in real commodity prices which has been a decisive factor in the debt performance of several countries, as for example Argentina, Bolivia or Peru, may well have bottomed out. Moreover, the recovery of real commodity prices may turn out to be surprisingly large and rapid.

Certainly the level of real commodity prices is unlikely to return to the high of the early 1970s because structural factors mitigate so large an increase. But a resumption of inflation and much lower real interest rates will drive up inventory demand and thus bring about a significant rise. Indeed, the signs of such an increase are already quite apparent except for food. In the one year to August 1987 the Economist index of all commodities increased in dollar terms by 22.1 percent, with industrial commodities rising by 46.4 percent. But that increase was not shared by food which showed a moderate decline. 


\section{CONCLUSION}

World macroeconomic policies and variables were until 1981-82 not the major reason for the present debt crisis. Only in 1981-82 did the sharp increase in interest rates and the decline in growth help create a crisis in the aftermath of very poor policy performance in debtor countries.

Since 1982 the world macroeconomic environment has shown an improvement. Interest rates declined in nominal and real terms and growth has been sustained, as was expected in 1982. The only surprises were that dollar overvaluation lasted as long as it did, a smaller decline in real interest rates and a massive decline in the real prices of commodities. The world macroeconomic environment certainly did not provide a setting in which debtor countries could grow out of their debts by export booms and improving terms of trade.

Today, five years into the adjustment process, indicators of creditworthiness show a deterioration except for the ratio of debt service to exports. And even that indicator is barely below the 1982 level. Can we expect that the world economy in the years ahead provides a distinctly more favorable setting? The IMF outlook for the period 1988-91 shows a no-news setting: steady, moderate growth, no changes in the terms of trade and an increase in real interest rates. In such an environment debtor countries would have to 
Morgan Guaranty (1986) World Financial Markets, April.

OECD (1986) Financing and External Debt of Developing Countries: 1985 Survey, Paris.

-- External Debt Statistics, Paris.

Sachs,J.(1986a) "Managing the LDC Debt Crisis" Brookings Papers on Economic Activity, 2.

(1987) "International Policy Coordination: The Case of the Developing Country Debt Crisis." NBER Working Paper Series No. 2287.

- Macroeconomic Policies in the OECD and LDC Economic Adjustment" Brookings Discussion Paper in International Economics, February.

Saunders,P. and A. Dean (1986) "The International Debt Situation and Linkages Between Developing Countries and the OECD." OECD Economic Studies, Autumn.

Truman, E. (1986) "The International Debt Situation" International Discussion Papers, No. 298, Board of Governors of the Federal Reserve, December.

World Bank, (1986) A Strategy for Restoration of Growth in Middle-1ncome Countries that Face Debt-Servicing Difficulties. No. 10. 
FOOTNOTES

${ }^{1}$ Countries in this group are characterized by having incurred arrears in 1983 and 1984 or rescheduled their debts in the 1982-85 period.

${ }^{2} 0 \mathrm{n}$ the costs of protection in a situation of credit rationing see Dornbusch (1985).

${ }^{3}$ See, for example, Dornbusch (1985, 1987).

${ }^{4}$ See International Monetary Fund (1986) and Dornbusch (1985).

${ }^{5}$ See IMF (1987b) pp.90-91 for a discussion of the data. 